\title{
Standard Language Ideology and the Non-Standard Adolescent Speaker
}

\author{
Shivonne M. Gates, Queen Mary University of London \\ Christian Ilbury, Queen Mary University of London
}

\section{Introduction}

Standard language ideology is pervasive (Cameron 1995), such that linguistic variation is overtly stigmatised. This is a global phenomenon: across the world it is common for some languages, varieties or dialects to be considered more prestigious than others. Perhaps these issues are not more discussed than in relation to the language spoken by young people. 'Youth speak' is regularly mocked in popular culture, misrepresented by the media and subject to intense scrutiny in education (e.g. BBC comedy Little Britain; Johns 2011; Dixon 2013). In this chapter we examine the ways in which standard language ideology constrains and affects adolescent speakers of British English varieties that are considered 'non-standard.' Specifically, we focus on discourses of standard language ideology present in the narratives of adolescents in London in two contexts: one institutional (a secondary school) and one social (a youth group). Building on work that has shown how standard language ideologies are ingrained in the education process and institutionalised in curricula (e.g., Trudgill \& Cheshire

\section{How to cite this book chapter:}

Gates, S.M. and Ilbury, C. 2019. Standard Language Ideology and the Non-Standard Adolescent Speaker. In: Wright, C., Harvey, L. and Simpson, J. (eds.) Voices and Practices in Applied Linguistics: Diversifying a Discipline, pp. 109-125. York: White Rose University Press. DOI: https://doi.org/10.22599/BAAL1.g. Licence: CC BY-NC 4.0 
1989), we illuminate how these ideologies transcend educational contexts and impact the lives of adolescents beyond the classroom. Although the data are from a specific UK context, the findings of this chapter are relevant to any situation in which adolescent language and identity are of interest.

We first discuss the background literature on standard language and youth styles, before introducing the sociolinguistic context of the two research projects. We then explore four themes present in the discourse: constraints and effects of standard language ideology, non-standard language as a 'cultural threat,' metalinguistic evaluations and the neo-liberal agenda. Through these four themes, we shed light on a broader discourse where negative evaluations of linguistic diversity are integrally linked to a neo-liberal educational agenda, in which using vernacular language is framed as a hindrance in preparing the individual for the workplace (Flubacher \& del Percio 2017). Throughout this chapter we use the terms non-standard and standard language. We acknowledge that these are contentious terms and do not ourselves ideologically align with this dichotomy but find the terms necessary to effectively interrogate the ideological positions we are problematising in this analysis (see Lippi-Green 2012: 61-62).

\section{Youth language and standard language ideology}

The language of adolescents is often considered problematic, with young people finding themselves marginalised or reprimanded for not speaking 'Standard English' (SE). In fact, standard language ideology is so pervasive (Cameron 1995), it is frequently claimed that youth styles are deficient (see the notion of 'Ghetto Grammar' in Johns 2011). In media, reports decry the language used by young people. Youth styles are often characterised as inauthentic, such as is implied by the term 'Jafaican' (Bindel 2013) - a blend of 'Jamaican' and 'fake' used to describe London adolescent speech. Others suggest that it has 'become a separatist form of communication' (Evening Standard 2010). To justify these claims, commentators have framed this narrative as a cause for concern, with young people's 'poor' linguistic skills limiting their opportunities beyond adolescence (Johns 2011). In popular culture, youth styles are routinely mocked, with television characters such as Little Britain's Vicky Pollard and The Catherine Tate Show's Lauren Cooper embodying crude personifications of the teenage 'chav' (Snell 2006), with their non-standard, 'inarticulate' linguistic skills central to the creation of humour.

These popular ideologies have implications for the educational experience of (some) adolescents. In recent years, some schools have taken drastic measures to 'improve' linguistic standards by imposing rules governing the use of language. In 2013, so-called 'slang' terms including 'innit,' 'bare' and sentence structures that begin with 'basically' were banned at an academy in South London (Fishwick 2013) and, in the same year, a primary school in the West 
Midlands imposed a ban on the use of the local Black Country dialect (Dixon 2013). In these contexts, schools justify such measures as a means to prepare students for life beyond adolescence. Specifically, the argument is that by outlawing linguistic features considered non-standard students' communication will improve, thus enabling them to become productive and efficient members of the workforce - a central tenet of the neo-liberal ideology which has guided educational policy on language instruction since the 1980s (Flubacher \& del Percio 2017).

But, while standard language ideology is pervasive, the notion of a spoken SE remains poorly defined and understood (see Trudgill 1999 for an overview). For instance, the marking schema of the Speaking and Listening assessment component of the English Language GCSE produced by the independent examination board AQA states that ' $[\mathrm{t}] \mathrm{o}$ be awarded a Pass, Merit or Distinction a Learner must ... use Spoken Standard English' (AQA 2015: 4). Likewise, in the National Curriculum administered by the Department for Education, it is specified that pupils should be taught to 'speak confidently, audibly and effectively ... using Standard English' (The National Curriculum 2014: 7). However, at no point in either the AQA marking criteria or the National Curriculum do the authors define what constitutes 'spoken Standard English.'

With the notion of SE enshrined in educational curricula, the distinction between SE and other varieties of English becomes a judgement of 'correctness' (Milroy 1999: 28), with the students' academic success contingent on the degree to which they demonstrate a command of SE. As Snell and Andrews (2016) have argued, this has potentially devastating social outcomes, where those who speak varieties assumed to be compatible with SE are given an advantage over their peers who speak local varieties.

Though these issues are by no means new (e.g., Labov 1972), in an increasingly diversifying world in which urban centres are often described as 'multicultural' (Cheshire et al. 2011), 'superdiverse' (Vertovec 2007), and even 'melting pots' (Tamasi \& Antieau 2015: 188), understanding and celebrating linguistic variation remains a pertinent issue. Yet, while there has been a consistent and sustained body of research examining dialect diversity, standard language ideology, and education in the US (e.g., Charity Hudley \& Mallinson 2010; Reaser et al. 2017; Lippi-Green 2012), there has been comparatively less research in the UK context (although see Cheshire \& Trudgill 1989; Rampton 1995; Snell 2013; Snell \& Andrews 2016 for notable exceptions). Contemporary research examining linguistic diversity in UK educational contexts has tended to focus more on the multilingual classroom or issues related to English language teaching (e.g., Harris, Leung \& Rampton 2001; Creese \& Blackledge 2010; Wei 2011; Pérez-Milans 2015). We take this empirical gap as a point of departure to examine how standard language ideologies constrain and affect speakers of varieties of English that are not considered SE. In particular, we focus on adolescent speakers in order to analyse the ways in which language ideologies are reinforced by educators and youth workers and, in turn, internalised by 
young people in their metalinguistic narratives. We demonstrate that, if applied linguistics is to effectively understand and present the nuances of diversity in multicultural contexts, a diversification of approaches is necessary. As such, we use an interdisciplinary toolkit of methods from linguistic ethnography and variationist sociolinguistics to examine non-standard speakers' discourses in relation to the ideologies that underpin them.

\section{The sociolinguistic context}

London is a multicultural metropolis. Throughout the 18th, 19th and 20th centuries, migrants into London have had ethnically diverse origins, from Europe, Asia, Africa and the Caribbean. The 21st century has seen continued in-migration from Africa, the Caribbean, South Asia and Eastern Europe. In 1948, the British Nationality Act granted citizenship to foreign nationals from within the British Commonwealth, encouraging migration to Britain at a time when labour was lacking. More recently, while the UK has been part of the $\mathrm{EU}$, free movement has been encouraged from a diverse number of European states, particularly those less affluent countries in Eastern Europe.

In addition to in-migration from outside of the UK, London has also seen a large degree of movement within and between boroughs. East London was traditionally a White working-class area: although there were ethnic minority communities in east London, the White population were in the majority. For complex social and economic reasons, including the changing labour market and the increasing cost of living in inner London, the White British population began moving further east to outer boroughs.

These two patterns of migration, in-migration from foreign nationals who are more often than not people of colour and out-migration of the traditional' White working-classes, are an important backdrop for our discussion of language ideology and adolescent language in London for several reasons. In multicultural contexts (in London and beyond), the narrative of 'tolerance' and inclusion is common. At first, this narrative seems positive: communities should welcome those from different cultural and linguistic backgrounds, and differences should be embraced. However, closer interrogation reveals that the inclusion narrative frames ethnic minorities and immigrants as other, different to the 'norm,' and something to be tolerated (Valluvan 2013).

This is further complicated by standard language ideology. As noted, 'nonstandard' ways of speaking, particularly working-class dialects, are stigmatised (Snell 2013). Negative evaluations of vernacular language can be further exacerbated when linguistic forms or varieties are not only considered non-standard but are also associated with ethnic minority groups (e.g., Jafaican). Over the last decade or so, Multicultural London English (MLE) has emerged as the language of working-class London adolescents. Although it is described as an ethnically neutral variety, MLE undoubtedly has roots in Caribbean, Asian, 
African and Arabic languages. More recent work has demonstrated that MLE can be used to index ethnic identities (Gates 2019) and varies stylistically in interaction (Ilbury forthcoming). We argue, then, that standard language ideologies have roots in social narratives about social class and race.

Given the sociohistorical context, the inner-city boroughs of east London are prime for intersecting cultural and social experiences. As such, the authors of this chapter conducted two ethnographic studies in two parallel but contrasting communities in the inner east London boroughs of Hackney and Newham. Both boroughs are ethnically and linguistically diverse places. At the most recent census in 2011, Hackney was 36\% White British, 11\% African, 8\% Caribbean, 3\% Indian and 3\% Bangladeshi - a diverse borough, but with larger White and Black communities than other ethnic groups. Newham was also diverse but with no dominant ethnic group: 17\% White British, 14\% Indian, 12\% Bangladeshi, 12\% African, 10\% Pakistani, 6\% Eastern or mixed European and $5 \%$ Caribbean. ${ }^{1}$

Ilbury conducted a 12-month ethnography (September 2016-2017) at Lakeside Youth Group in Hackney. Lakeside was open during the evenings Monday to Friday, and during fieldwork Ilbury attended the youth group up to four times a week. Members were working-class, predominantly of Afro-Caribbean heritage, with some White British and mixed-race (Black and White British) individuals. Participants were aged 11-17, and data were collected through observation, interviews and self-recordings. Approximately 50 teenagers attended the youth group but, since attendance was not compulsory, this was variable. Audio data were collected through self-recordings from 25 adolescents - 15 boys and 10 girls. Sixteen of these participants were also interviewed.

Gates conducted a 12-month ethnography at Riverton Secondary School, located in the borough of Newham. This working-class, ethnically diverse school had a student body of approximately 850 students aged 11-16 at the time of data collection (April 2015-2016). The school day ran from 8.45am to $3.25 \mathrm{pm}$ Monday to Friday with five lessons, a morning break and lunch period. Gates attended lessons and went to break and lunch three to five days a week during the fieldwork period. After approximately four months of participant observation, interviews were conducted with the Year Ten cohort (aged 14-15). Twenty-seven students were interviewed - 19 girls and eight boys. They were an ethnically mixed group, representative of the demographics of the borough, with no dominant ethnic group. Self-identified ethnicities among the study participants included Bengali, Pakistani, Ghanaian, Nigerian, Vietnamese, Somalian, St Lucian, Latvian and White British.

\section{Constraints and effects of standard language ideology}

The first theme we explore concerns the way in which the young people explicitly frame their language in opposition to SE. In excerpt 1, Kieran and Natalie 
(Lakeside) have just been presented a series of flashcards. The purpose of this task was to elicit metalinguistic discussions regarding lexical items such as peng (attractive/good), glowed up (became more attractive) and bare (lots of/ very), which were recorded in the researchers' field notes prior to interviewing the individuals. Most of these words are well documented as features of London (and UK-wide) urban vernaculars (e.g., Cheshire et al. 2011; Drummond 2018). In the ensuing discussion, Kieran and Natalie discuss the flashcards presented to them, framing these words in terms of respect:

\section{Excerpt 1}

1 Kieran: In school, I'm completely - I don't say them in school....

$2 \quad$ When I'm in school, I'm more - what's the word?

3 Considerate in what words I use. ... But sometimes I do

4 say those words, but I know to myself I shouldn't really.

5 Interviewer: Why?

6 Kieran: 'Cause, like, I know when when I'm talking to adults,

7 they don't speak the way we do 'cause they're from a different generation, so -

8 Natalie: They'll find it disrespectful.

9 Kieran: Yeah, they'll find it disrespectful. They might find it disrespectful to speak to them, er, in that way.

In lines 1-2 and 6-7, Kieran explicitly conceptualises the use of the words presented to him in terms of their contextual appropriateness, stating that he does not 'say them in school' (line 1) and that he does not say them when 'talking to adults (line 6). This suggests that there is a conscious awareness of the register appropriateness of using what he deems later to be 'slang' in specific contexts. As such, claims that young people are unable to code-switch (see Johns 2011) appear to be unsupported. Rather, Kieran gives a nuanced account of stylistic variation, describing that he would adapt his language to both the recipient (line 6: 'when I'm talking to adults') and the context of the interaction (line 1: 'in school'). Nevertheless, he concedes that occasionally he will use those words in what he deems contextually inappropriate settings (line 3). This is expected given that style-shifting can only occur within realistic limits (Charity Hudley \& Mallinson 2011). However, when he does 'slip-up,' in lines 2-3 Kieran frames this as an internalised trope of moral obligation ('I know to myself I shouldn't'). In doing so, he relates his language to an expectation of 'correct' personal conduct (Cameron 1995; Milroy 1999) - a notion that the hegemony of a standard language ideology depends upon.

Themes of appropriateness apparent in Kieran's narrative are based on the more general claim that using non-standard language is 'disrespectful' (lines 8-10), a stance with which Natalie aligns herself (line 8). This is a prevalent 
theme, including in excerpt 2 where language is, again, framed in terms of conduct. Here, Paul and David (ages 12 and 15, respectively, Lakeside) are discussing being reprimanded at school, with most of the conversation focusing on detentions. While one would expect such discussions to focus on unruly conduct and behaviour, it is language that is the primary source of contention.

\section{Excerpt 2}

1 Interviewer: What do they tell you off for though?

2 ...

3 Paul: $\quad$ Being rude, like with them words.

4 Interviewer: With them words?

5 ...

6 David: Well, you see in life, yeah? Like, you see in school, my teacher will get mad 'cause she'll be like, 'Ah, you're not from the streets', you know, blah blah blah. Or, 'Don't bring

9 my street in h- don't bring the streets in my, um, school'.

In line 1, Ilbury asks an open-ended question to ascertain what 'they tell you off for.' At this point, the individuals were not explicitly asked to discuss language. But in line 3 Paul states that he is disciplined because he uses 'them words.' In this context, 'them words' refers to the flashcards that were presented to Paul and David earlier, as in extract 1. As noted, the flashcards are words often described as 'slang' but the meanings that they refer to are diverse and few directly reference inappropriate behaviours. They are therefore unlikely to be considered 'rude' in any objective sense. Nevertheless, in Paul's narrative, 'being rude' is directly attributed to using 'them words' (line 3). This notion of politeness was implicit in Kieran's earlier discussion of appropriateness and respect in excerpt 1. Thus, in both excerpts, a link is drawn between non-linguistic conduct (respect) and SE - a well-established trope that educators and gatekeepers maintain as a proxy for establishing 'good' conduct (Cameron 1995: 108; Flubacher \& del Percio 2017).

In the ensuing discussion, David attempts an explanation of why certain types of language may be deemed by teachers as 'rude' or 'disrespectful.' Specifically, he draws on his own personal experience in which a teacher reprimands him for using language deemed inappropriate for the classroom. In this situation, the teacher makes an indexical association between non-standard language and a 'street' identity (line 7), in which she draws directly on the narrative which fetishises youth styles as 'ghetto grammar' (e.g., Johns 2011). Here, the teacher has indirectly reified the 'types' of English that are considered appropriate for the classroom and conducive to educational attainment - of which SE is perceived to be the only type. In line 7, we see that the acceptability of his speech style is based on the teacher's perception of youth styles as an 
inauthentic performance ('you're not from the streets'), thereby diminishing the legitimacy of that variety. The real-world implications of this is seen in line 7, where David claims that when a 'non-acceptable' speech style is used and there is a 'violation' of institutional expectations, his teacher would get 'mad' (line 7), resulting in him being reprimanded.

\section{Non-standard language as a 'cultural threat'}

It seems likely, then, that perceptions of non-standard language as 'rude' result from misunderstandings on the part of the linguistic gatekeeper (e.g., teacher, youth worker). One such misinterpretation is related to non-standard language as a 'cultural threat'. Although this concept is most often used to describe perceptions of minority immigrant communities (e.g., Newman, Hartman \& Taber 2012; Medeiros, Fournier \& Benet-Martínez 2016), we argue that the notion of cultural threat is helpful in explaining how educators maintain standard language ideology in the classroom. Specifically, the speech styles used by the individuals in our studies are often framed as 'foreign' languages. For instance, consider excerpt 3:

\section{Excerpt 3}

1 Kieran: I didn't expect these types of words to be coming up.

2 Interviewer: Why, what kind of words did you think I was -

3 Kieran: Normal words.

4 Interviewer: W- well what are these then?

5 Kieran: They're like - colloquial language, like -

6 Interviewer: Right.

7 Kieran: it's not - it's words that are not in the English dictionary

8 Interviewer: Well what are the reasons you use it for?

9 Kieran: We use it for slang instead of actual English.

In excerpt 3, we return to a discussion of the flashcards presented to Kieran and Natalie (see excerpt 1). In this example, we see that Kieran frames the words that are presented to him as words that are not 'actual English [words]' (line 9). Prevalent throughout is the notion that the words presented to him and Natalie are not part of the English language but constitute a different system entirely. As Kieran states in line 3, he was expecting 'normal words,' (i.e., words that appear in the 'English dictionary') (line 7). 'Normal' words here appears to be a proxy for SE. Thus, his assertion that the words are used 'for slang' (line 9) fits in well with a more general issue that young people regularly describe their speech (i.e., not just lexis) as 'slang.' This is likely to be reflective of an internalised 
trope that is prevalent in media and education, which over-essentialises youth styles as 'slang' (e.g., Johns 2011).

Of course, Kieran is using English, but these claims evoke media narratives that 'youth speak' is, itself, a distinct language (e.g., The Evening Standard 2010). Essentially, what we see here is a conceptualisation of non-standard language as a 'foreign language,' where the use of this style is perceived by teachers to be a 'threat' to English - themes prevalent in narratives of minority languages (see Newman, Hartman \& Taber 2012).

In excerpt 4 , the issue of cultural threat is compounded where Isaac is reprimanded after complaining to a teacher that another student had stepped on his 'creps' (trainers). In the ensuing discussion, although it is Isaac who made the original complaint, it is he who ends up receiving punishment - 'a six o'clock' (a detention, line 10):

\section{Excerpt 4}

1 Isaac: I said, 'Ah, Miss, he was step- argh h- thing this boy was

$2 \quad$ step- stepped on my creps!'

3 Interviewer: Yeah yeah.

4 Isaac: Then she was like what's creps?

5 Interviewer: Oh-hmm.

6 Isaac: I said - I said, 'Oh, shoes.' Then she was like, 'You shouldn't

7 use them - you shouldn't use their lan- you shouldn't use that language.'

$8 \quad$ I said, 'Why? What's wrong with it?'

9 Interviewer: Yeah.

10 Isaac: She said, 'Give me your planner.' She gave me a six o'clock, 11 I didn't go.

12 Interviewer: ... Why, cause you think she doesn't understand it you got excluded?

14 Isaac: Yeah, cause she doesn't understand it.

In line 4 , the teacher asks for clarification as to the meaning of 'creps,' to which Isaac gives an accurate definition (line 6). However, in the following lines (6-7) the teacher emphasises the incompatibility of non-standard language and the classroom framing this as a 'moral judgment' (Cameron 1995) - 'you shouldn't use that language' (line 7). In what follows, the misunderstanding and incompatibility of this style is perceived by the teacher as a threat, in which the potential for 'creps' to refer to some rude or inappropriate entity results in the teacher curtailing his behaviour by issuing him with a detention. The avoidable situation here, caused by a misinterpretation of the referent of 'creps,' is dependent on the themes discussed in previous sections: that non-standard ways of speaking are ideologically fetishised as 'street' and therefore, either 
indirectly or directly, related to criminal activities (e.g., The Evening Standard 2010; Johns 2011). Thus, based on this erroneous ideological connection, the teacher assumes that the entity that Isaac is referring to is potentially rude or insulting (see extracts 1 and 2). In lines following, Ilbury clarifies the cause of the misinterpretation ('cause you think she doesn't understand it', line 11), with Isaac confirming that it is the teacher's misunderstanding that resulted in him being sanctioned (line 12).

\section{Metalinguistic evaluations}

Building on the analyses presented thus far, the following excerpts demonstrate explicit awareness of classed and racialised language. These types of metalinguistic evaluations reflect and construct standard language ideologies: the examples below highlight the pervasiveness of the ideology that SE is the unmarked form spoken by White British middle-class speakers. This in turn reiterates the abstract nature of SE and demonstrates processes of linguistic subordination (Lippi-Green 2012), as language that represents a marked class and/or ethnic identity is considered 'bad English'. Excerpts 5 and 6 provide explicit examples of this type of enregisterment.

\section{Excerpt 5}

1 John: Like - You see the White girls when they're talking? They

2 have that - 'Alright!' - Like that. Yeah. Like, if posh

3 people hear that, then they're gonna be like, 'Ah, these people, they're lower class,' this and that. Yeah.

Excerpt 5 is an interview with John - a Black British 15-year-old male from Riverton Secondary School. In this excerpt, John and the interviewer (Gates) were discussing different ways that John's school peers spoke. In John's year group, the popular girls' peer groups were organised by ethnic group. Their peer group labels directly referenced these intentional groupings, a clear example of ethnic homophily (McPherson, Smith-Lovin \& Cook 2001). This is just one example of the social importance of ethnicity in this community, which is important context for this extract.

In line 1, John explicitly references the ethnicity of a specific group of girls: 'the White girls.' Here, he is referring to the White Squad peer group, who are all White British. He then imitates their accent with the word 'alright' in line 2, a word choice that is not insignificant. The second vowel in 'alright' is from the PRICE lexical set (Wells 1982). In British English, the PRICE vowel has an open back onset and then a glide that moves towards a front, close offset. Recent sociophonetic research has found that this vowel has shifted dramatically in 
London English over the last 30 years, to be realised with a more front, close onset that is in some instances monophthongal (Gates 2018; Kerswill, Torgersen \& Fox 2008). In his imitation, John produces an exaggerated, open diphthong in 'alright', a clear reference to the fact that the White British girls in this community have a markedly different pronunciation to their peers that aligns more closely with the more traditional diphthongal realisation (this observation is supported by the quantitative analyses of acoustic data in Gates 2018). John then presents this pronunciation in opposition to being 'posh,' noting that this accent would not only be regarded as different by middle- or upper-class speakers, but it would be directly associated with lower social classes, leading to a negative value judgement of that speaker.

Excerpt 5 highlights two key points. First, it illuminates adolescents' awareness of social stigmas associated with certain vernaculars. Second, it picks up on the connection between language and groups of people. As noted by LippiGreen (2012), language serves as a proxy through which (groups of) people are stigmatised.

Excerpt 6 is from the Lakeside data set. Here, the interviewer (Ilbury) is talking with two girls from the youth group, Charice and Daniella. Charice is Black British and has one Jamaican and one White British parent. Daniella is mixedrace, with one Turkish parent and one parent from Trinidad and Tobago. For broader context, this excerpt is from a conversation about racialised discourses and institutional racism. Ilbury asks about the word roadman, which Charice describes as being 'like those Turkish boys who act black', leading to the discussion in excerpt 6.

\section{Excerpt 6}

1 Interviewer: What's 'acting Black' mean though, like how would you

$2 \quad$ classify someone as acting Black?

3 Charice: Oh my gosh!

4 Daniella: Black - hmmm, I don't really wanna sound racist.

5 Charice: Tryna - yeah.

6 Interviewer: No, no, no, it's not racist, it's just -

7 Daniella: The White people talk formally. The way they talk is

8 different, don't you think? They m- mostly talk formally.

This extract is an example how colour-blind discourses work in tandem with standard language ideology. The theory of colour-blindness has emerged out of complex racial and sociopolitical contexts integrally linked to neo-liberalism and results in the minimisation or erasure of the experiences of people of colour (for detailed discussion, see Bonilla-Silva 2014; Omi \& Winant 2014). For White adolescents in America, the interactional delicacy of talking about race is evident in racial evasion: attempting to avoid or circle around race as a result 
of structural colour-blind discourses (Bucholtz 2011: 168). These discourses are so pervasive that they are even replicated by adolescents of colour in London. In excerpt 6 , line 4, Daniella explicitly states that she does not want to 'sound racist' in a discussion of what it means to 'act black.' After some prompting, Daniella connects 'formal' speech with whiteness, reframing her characterisation of 'acting black.' This highlights how colour-blind discourses prevent adolescents of colour from articulating their own experiences, and also how race is further removed from the conversation by standard language ideology.

\section{Neo-liberal agenda}

A key component of our argument is that the neo-liberal agenda is highly influential when it comes to standard language ideology (Flubacher \& del Percio 2017). By referring to the 'neo-liberal agenda', we intend to draw attention to the fact that, in Britain, young people's life paths are primarily negotiated through education, which is all intended to have the same outcome: that they are productive adult members of society by being active participants in the labour market. Of course, there are many ways in which one can contribute to society, but neo-liberalism prioritises capitalist wealth. With this in mind, we suggest that the neo-liberal agenda plays an integral role in constructing and reproducing standard language ideologies. This argument is, in part, supported by the three areas of focus presented thus far, but the following excerpts make this theme explicit.

\section{Excerpt 7}

1 Amy: $\quad$ Everyone just finds it funny, how I talk, but I don't really know why.

2 Interviewer: So what, you just like ... have a different way of speaking?

3 Amy: $\quad$ Yeah, I think so because - We just - from, sort of, round

4 here and some people are not. Or they've come up with different backgrounds.

5 Interviewer: So do you - do you like the way that you speak, or?

6 Amy: Yeah. I guess. Like, I suppose if I was to go to interviews

7 and that I would have to be more formal. 'Cause I just say

8 like, 'ain't' and stuff like that. But I think I would need to

9 be more formal when I speak. I dunno.

10 Interviewer: Yeah.

In excerpt 7, Amy and the interviewer (Gates) are discussing different ways of speaking, a topic of conversation that arose earlier in the interview. Amy is a White British girl who lives close to her school. She has always lived in the area, 
and both of her parents are White British, born in London. This excerpt is of particular interest, as Amy not only highlights that different ways of speaking have different social evaluations attached to them and are associated with different social groups, but also that adolescents are aware of what the (perceived) ramifications of using 'improper' language might be. Amy is acutely aware of the fact her own vernacular is stigmatised, noting that her peers find her way of speaking 'funny' (line 1). However, the relationship between language and local identity is also alluded to in lines 3-4, when Amy notes that her way of speaking is because she is from 'round here.' Stating this immediately after acknowledging the social status of her vernacular highlights the tension between linguistic identity and standard language ideology. This is further demonstrated in line 7, where Amy references a specific feature of her vernacular: 'ain't,' a present tense negative form of the BE verb. In emphasising this feature, she demonstrates her awareness of this marked feature, conceptualising its use in terms of formality. It could be argued that, in this instance, formality is being used as a proxy for the abstract concept of SE. Lines 6-8 also suggest that Amy considers having an 'interview style' is an important life skill. This seems to have been born out of the neo-liberal narratives mentioned above, that position ones contribution to the labour market as a primary measure of being a productive member of society.

\section{Excerpt 8}

1 Krista: I don't think he does though, h- he's - out of all the boys, 2 he's - he's the most - um - determined, in terms of 3 education.... So - he's quite formal as well. When he speaks.

In excerpt 8, we see explicit evidence of the positive framing of standard language and its association with aspirations and achievement. As part of a discussion about different ways of speaking among her peers, Krista uses Ade as an example of someone who is aspirational. Both Krista and Ade are of immigrant backgrounds (Krista's family is Latvian, and Ade's is Nigerian) but, although both are impressionistically ${ }^{2}$ speakers of London English, neither uses any stereotypical phonological or morphosyntactic features of MLE (as in Cheshire et al. 2011). As such, they could both be considered to speak a more 'standard' variety of the local vernacular. They are both members of (different) popular peer groups, they work hard in school and they are high achievers. In this excerpt, Krista frames Ade's aspirational nature as being related to the way that he speaks. As she puts it, he 'doesn't speak slang', which implies that his vernacular is less marked than Amy's from excerpt 7. This supports the impressionistic assessment of Ade's speech.

Krista then goes on to describe Ade as 'quite formal... when he speaks' in lines 2-3. This is parallel to her description of him as 'determined, in terms of education.' Again, as with Amy in excerpt 7, the notion of formal speech 
seems to be a proxy for SE. Positioning these descriptions in this way is indicative of the perceived relationship between using SE and orientation towards education. As with excerpt 7, this highlights the influence of neo-liberalism on language ideologies: doing well in school is a necessary stepping stone to being a productive adult in society, and in order to do these things one must speak SE.

\section{Conclusion}

In this chapter we have used empirical data to examine four themes, arguing that 'non-standard' varieties, particularly those deemed 'youth styles,' are frequently characterised as deficient. The data show that speakers internalise standard language ideologies, which we argue is driven by a wider neo-liberal campaign that views 'non-standard' language as a hindrance to the development of a productive workforce (Flubacher \& del Percio 2017). And while standard language ideology is maintained in curricula and by educators, we have shown that the effects of such narratives transcend educational contexts and influence adolescents outside of the institution, having potentially damaging effects on 'non-standard' vernacular speakers. This finding is likely not unique to the British context, given the globally pervasive nature of standard language ideology. Therefore, we argue that, in a period of time where urban centres are increasingly diverse, educators in Britain and beyond must make conscious efforts to understand and integrate dialect diversity into their practice.

\section{Endnotes}

${ }^{1}$ It should be noted that, while the authors acknowledge that census categories are deeply problematic, it is beyond the scope of this chapter to discuss this in detail.

${ }^{2}$ In variationist sociolinguistics, impressionistic analysis refers to the use of auditory impressions rather than instrumental analysis.

\section{References}

AQA 2015 Spoken language endorsement for GCSE English Language. Available at http://filestore.aqa.org.uk/resources/english/AQA-8700-SLENDORSEMENT.PDF

Bindel, J. 2013 From Cockney to Jafaican. The Spectator. Available at https:// www.spectator.co.uk/2013/03/slanging-match.

Bonilla-Silva, E. 2014 Racism without racists: Colorblind racism and the persistence of racial inequality in America. 4th ed. Plymouth: Rowman \& Littlefield. 
Bucholtz, M. 2011 White kids: Language, race and styles of youth identity. Cambridge: Cambridge University Press.

Cameron, D. 1995 Verbal hygiene. London: Routledge.

Charity Hudley, A.H. and Mallinson, C. 2010 Understanding English language variation in U.S. schools. New York: Teachers College Press.

Cheshire, J., Kerswill, P., Fox, S. and Torgersen, E. 2011 Contact, the feature pool and the speech community: The emergence of Multicultural London English. Journal of Sociolinguistics, 15(2): 151-196. DOI: https://doi. org/10.1111/j.1467-9841.2011.00478.x.

Creese, A. and Blackledge, A. 2010 Towards a sociolinguistics of superdiversity. Zeitschrift für Erziehungswissenschaft, 13(4): 549-572. DOI: https://doi. org/10.1007/s11618-010-0159-y.

Dixon, H. 2013 Midlands primary school bans pupils from using Black Country dialect. The Telegraph. Available at https://www.telegraph.co.uk/education/ educationnews/10449085/Midlands-primary-school-bans-pupils-fromusing-Black-Country-dialect.html.

Drummond, R. 2018 Researching urban youth language and identity. Basingstoke: Palgrave Macmillan.

Fishwick, C. 2013 London school bans pupils from using 'innit,' 'like', and 'bare'. The Guardian. Available at http://www.theguardian.com/uknews/2013/ oct/15/london-school-bans-pupils-slang-innit.

Flubacher, M.-C. and del Percio, A. 2017 Language, education and neoliberalism. Bristol: Multilingual Matters.

Gates, S.M. 2018 Why the long FACE: Ethnic stratification and variation in the London diphthong system. University of Pennsylvania Working Papers in Linguistics, 24(2): 6.

Gates, S.M. 2019 Language variation and ethnicity in a multicultural East London secondary school. Unpublished PhD thesis. London: Queen Mary University of London.

Harris, R., Leung, C. and Rampton, B. 2001 Globalisation, diaspora and language education in England. In Block, D. and Cameron, D. (eds), Globalisation and language teaching. London: Routledge. pp. 29-46.

Ilbury, C. (forthcoming) Beyond the offline: Social media and the social meaning of variation in east London. Unpublished PhD thesis. London: Queen Mary University of London.

Johns, L. 2011 Ghetto grammar robs the young of a proper voice. The Evening Standard. Available at http://www.standard.co.uk/news/ghetto-grammarrobstheyoung-of-a-proper-voice-6433284.html.

Kerswill, P., Torgersen, E. and Fox, S. 2008 Reversing 'drift': Innovation and diffusion in the London diphthong system. Language Variation and Change, 20: 451-491.

Labov, W. 1972 Academic ignorance and black intelligence. The Atlantic Monthly, 229(6): 59-67.

Lippi-Green, R. 2012 English with an accent: Language, ideology and discrimination in the United States. 2nd ed. London: Routledge. 
McPherson, M., Smith-Lovin, L. and Cook, J. 2001 Birds of a feather: Homophily in social networks. Annual Review of Sociology, 27(1): 415-444. DOI: https://doi.org/10.1146/annurev.soc.27.1.415

Medeiros, M., Fournier, P. and Benet-Martínez, V. 2016 The language of threat: Linguistic perceptions and intergroup relations. Acta Politica, 52(1): 1-22. DOI: https://doi.org/10.1057/s41269-016-0023-z

Milroy, J. 1999 The consequences of standardisation in descriptive linguistics. In Bex, T. and Watts, R. (eds), Standard English: The widening debate. Abingdon: Routledge. pp. 16-39.

Newman, B., Hartman, T. and Taber, C. 2012 Foreign language exposure, cultural threat, and opposition to immigration. Political Psychology, 33(5): 635-657. DOI: https://doi.org/10.1111/j.1467-9221.2012.00904.x

Omi, M. and Winant, H. 2014 Racial formation in the United States. 3rd ed. London: Routledge.

Pérez-Milans, M. 2015 Mandarin Chinese in London education: Language aspirations in a working-class secondary school. Language Policy, 14(2): 153-181. DOI: https://doi.org/10.1007/s10993-014-9345-8

Rampton, B. 1995 Crossing: Language and ethnicity among adolescents. London: Longman.

Reaser, J., Temple Adger, C., Christian, D. and Wolfram, W. 2017 Dialects at school: Educating linguistically diverse students. New York: Routledge.

Snell, J. and Andrews, R. 2016 To what extent does a regional dialect and accent impact on the development of reading and writing skills? Cambridge Journal of Education, 47(3): 297-313. DOI: https://doi.org/10.1080/03057 64X.2016.1159660

Snell, J. 2006 Schema theory and the humour of Little Britain. English Today, 22(1): 59-64. DOI: https://doi.org/10.1017/S0266078406001118

Snell, J. 2013 Dialect, interaction and class positioning in school: From deficit to difference to repertoire. Language and Education, 27(2): 110-128.

Tamasi, S. and Antieau, L. 2015 Language and linguistic diversity in the US: An introduction. New York: Routledge.

The Evening Standard 2010 The secret world of gang slang. Available at https:// www.standard.co.uk/lifestyle/the-secret-world-of-gang-slang-6530868. html [Last accessed 3 January 2019].

The National Curriculum 2014 Available at: https:/www.gov.uk/government/ publications/national-curriculum-in-england-english-programmes-ofstudy/national-curriculum-in-england-english-programmes-of-study [Last accessed 3 January 2019].

Trudgill, P. and Cheshire, J. 1989 Dialect and education in the United Kingdom. In Cheshire, J., Edwards, V., Münstermann, H. and Weltens, B. (eds), Dialect and education: Some European perspectives. Clevedon: Multilingual Matters. pp. 94-109.

Trudgill, P. 1999 Standard English: What it isn't. In Bex, T. and Watts, R. (eds), Standard English: The widening debate. London: Routledge. pp. 117-128. 
Valluvan, S. 2013 The status of multiculturalism and the retreat from difference. In Kapoor, N., Kalra, V. and Montague Rhodes, J. (eds), The state of race. Basingstoke: Palgrave Macmillan. pp. 72-95.

Vertovec, S. 2007 Super-diversity and its implications. Ethnic and Racial Studies, 30(6): 1024-1054. DOI: https://doi.org/10.1080/01419870701599465

Wei, L. 2011 Multilinguality, multimodality and multicompetence: Code- and mode-switching by minority ethnic children in complementary schools. Modern Language Journal, 95(3): 370-384. DOI: https://doi.org/10.1111/ j.1540-4781.2011.01209.x

Wells, J. 1982 Accents of English. Cambridge: Cambridge University Press. 